\title{
Demography of Dhampus: A Community Health Diagnosis Field Visit Report
}

\author{
Poudel S*, Ghimire UR, Sanjeeb KC, Kunwar S, Mehta R, Niraula S, Yadav R, Parajuli R, Regmi S, Bohara S, Subedi \\ S, Chimariya S, Parajuli S, Poudel A, Lohani S, Maharjan S, Rayamaji S, Mahato S, Adhikari S, Pageni S, Udaya S, \\ Karki B, Shrestha S, Faujdar S, Malla S, Paudel S, Bhatta S, Shrestha S, Shrestha S, Budha YDM
}

\author{
Keywords \\ Community health diagnosis, Dhampus, \\ Demography.

\section{Corresponding author} \\ **Dr. Sandip Poudel, $3^{\text {rd }}$ year MBBS \\ Gandaki Medical College \& Teaching \\ Hospital, Pokhara, Nepal \\ Email: sandippoudel2054@gmail.com
}

\begin{abstract}
Community health diagnosis is a comprehensive assessment of health status of the community in relation to its social, physical and biological environment. The purpose of community health diagnosis is to define existing problems, determine available resources and set priorities for planning, implementing and evaluation health action, by and for the community. A cross sectional descriptive study was done at Dhampus VDC from 1 Sept 2016 AD (16 ${ }^{\text {th }}$ Bhadra, 2073 BS) to 16 Sept 2016 AD (31 ${ }^{\text {st }}$ Bhadra, 2073). The data was collected by questionnaires, anthropometric measurements, interviews and secondary data. The community health diagnosis field visit gave us the opportunity to build our team spirit and taught us the arts of problem solving. It taught us the importance of correct conduct and building a good rapport with the people who were unfamiliar to us.
\end{abstract}

\section{INTRODUCTION}

Demography is the scientific study of human population based on population composition, its distribution in space and changes in population size. Health in a group depends on dynamic relationship between these factors. Hence demography is of vital importance in community health diagnosis (CHD).

The term demography is derived from two Greek words: Demos= People, Graphian $=$ to draw or describe. It deals with three observable human phenomena:

a) Changes in population (Growth or decline)

b) Composition of population

c) Distribution of population in space

And five demographic processes namely fertility, mortality, marriage, migration and divorce. Besides disability, morbidity, literacy etc can also be noted. It gives general idea about the community for planning and formulating health policies and programs and to measure health status by the authorities.

\section{OBJECTIVES}

a) To determine the demographic and socioeconomic indicators to assess the health status of the community.

b) To present our findings to the community and receive feedback.

c) To prepare a report on the survey and submit it to the Department of Community Medicine, Gandaki Medical College, Lekhnath, Kaski, Nepal.

\section{METHODS}

Study Area: Dhampus VDC

Study design: Cross-sectional descriptive study. In a cross-sectional study, measurement of exposure and effect are made at the same time.

Study period: 1 Sept $2016 \mathrm{AD}$ (16 ${ }^{\text {th }}$ Bhadra $\left.2073 \mathrm{BS}\right)$ to 16 Sept 2017 AD (31 ${ }^{\text {st }}$ Bhadra 2073 BS) 
Process: Household survey

Survey unit: 410 households out of 620

Survey Duration: 15 days

Survey techniques: Every available household was covered in survey but there was limitation as many houses were inhabited due to migration, earthquake and Teej festival.

Table 1: Survey techniques, tools and respondents

\begin{tabular}{lll}
\hline \multicolumn{1}{c}{ Techniques } & \multicolumn{1}{c}{ Tools } & \multicolumn{1}{c}{ Respondents } \\
\hline Household survey & Questionnaires & $\begin{array}{l}\text { Household } \\
\text { heads, mothers, } \\
\text { eligible couples }\end{array}$ \\
$\begin{array}{lll}\text { Anthropometric } \\
\text { measurements }\end{array}$ & $\begin{array}{l}\text { Tailor's tape, } \\
\text { weighing ma- } \\
\text { chine }\end{array}$ & $\begin{array}{l}\text { 1-5 year old } \\
\text { children }\end{array}$ \\
Observation & $\begin{array}{l}\text { Observation } \\
\text { check-list }\end{array}$ & - \\
& $\begin{array}{l}\text { Semi struc- } \\
\text { tured interview } \\
\text { guidelines }\end{array}$ & FCHVs \\
\hline
\end{tabular}

\section{FINDINGS OF THE COMMUNITY}

\section{Population size and its composition}

Population is defined as total number of people living in a particular place in a particular time. According to the data collected from the VDC office of Dhampus, VDC consists of 620 households with total population of 2537.

According to the data collected from survey, we surveyed 410 households with total population of 1732 .

a) Sex ratio: It was found to be 92.01 being the population of males slightly higher than the females.

b) Dependency Ratio: It was found to be 52.19 i.e. 100 economically active (15 - 59 years) have to support about 53 dependent people (children below 15 years and elders above 59 years).

c) Median age: Median age was found to be 28 .

d) Fertility: Total live births in last one year were found to be 38. CBR was calculated to be 22.5 per thousand populations per year e) Mortality: Total deaths in last one year were found to be 10 . CDR was calculated to be 5.8 per thousand population per year. IMR was found to be zero.

f) Morbidity: Total number of diseased persons in last one month was found to be $6.29 \%$ of total population.

g) Disability: Total number of disabled people was found to be four.

Table 2: Population size and its composition of Dhampus VDC

\begin{tabular}{|c|c|c|}
\hline Indices & $\begin{array}{l}\text { Figures } \\
\text { obtained }\end{array}$ & $\begin{array}{l}\text { National data } \\
(2011)\end{array}$ \\
\hline Sex ratio & 92.01 & 94.2 \\
\hline $\begin{array}{l}\text { Median age } \\
\text { (years) }\end{array}$ & 28 & 22.1 \\
\hline $\begin{array}{l}\text { Average family } \\
\text { size }\end{array}$ & 4.23 & 4.88 \\
\hline Literacy rate & $61.87 \%$ & $65.9 \%$ \\
\hline Dependency ratio & $52.19 \%$ & $75.55 \%$ \\
\hline Disability rate & $0.23 \%$ & $1.94 \%$ \\
\hline $\begin{array}{l}\text { Fertility: } \\
\text { A) Crude birth } \\
\text { rate }\end{array}$ & $\begin{array}{l}22.5 \text { per } \\
1000\end{array}$ & 21.85 per 1000 \\
\hline $\begin{array}{l}\text { Mortality: } \\
\text { A) Crude death } \\
\text { rate }\end{array}$ & $\begin{array}{l}5.8 \text { per } \\
1000\end{array}$ & 6.75 per 1000 \\
\hline $\begin{array}{l}\text { B) Infant mortal- } \\
\text { ity rate }\end{array}$ & 0 & $\begin{array}{l}43.13 \text { deaths per } \\
1000 \text { live births }\end{array}$ \\
\hline
\end{tabular}

IMR was found to be zero, probably because people didn't want to disclose about their family matters as it may revive the emotional trauma of the family and especially mother would be more affected.

\section{Age-sex composition}

Age and sex is a vital component of population which have direct effect on the structure, social and economic aspects of population. The age-sex composition of Dhampus VDC is given in following Table 
Table 3: Age and sex composition of Dhampus VDC

\begin{tabular}{ccc}
\hline Age (Years) & Males & Females \\
\hline $0-4$ & 56 & 34 \\
$5-9$ & 54 & 50 \\
$10-14$ & 71 & 87 \\
$15-19$ & 105 & 109 \\
$20-24$ & 98 & 82 \\
$25-29$ & 97 & 73 \\
$30-34$ & 57 & 56 \\
$35-39$ & 54 & 62 \\
$40-44$ & 50 & 42 \\
$45-49$ & 47 & 43 \\
$50-54$ & 44 & 47 \\
$55-59$ & 37 & 37 \\
$60-64$ & 45 & 36 \\
$65-69$ & 34 & 19 \\
$70-74$ & 21 & 27 \\
$75-79$ & 18 & 14 \\
$80+$ & 14 & 12 \\
\hline
\end{tabular}

Fig 1: Age and sex composition of Dhampus VDC

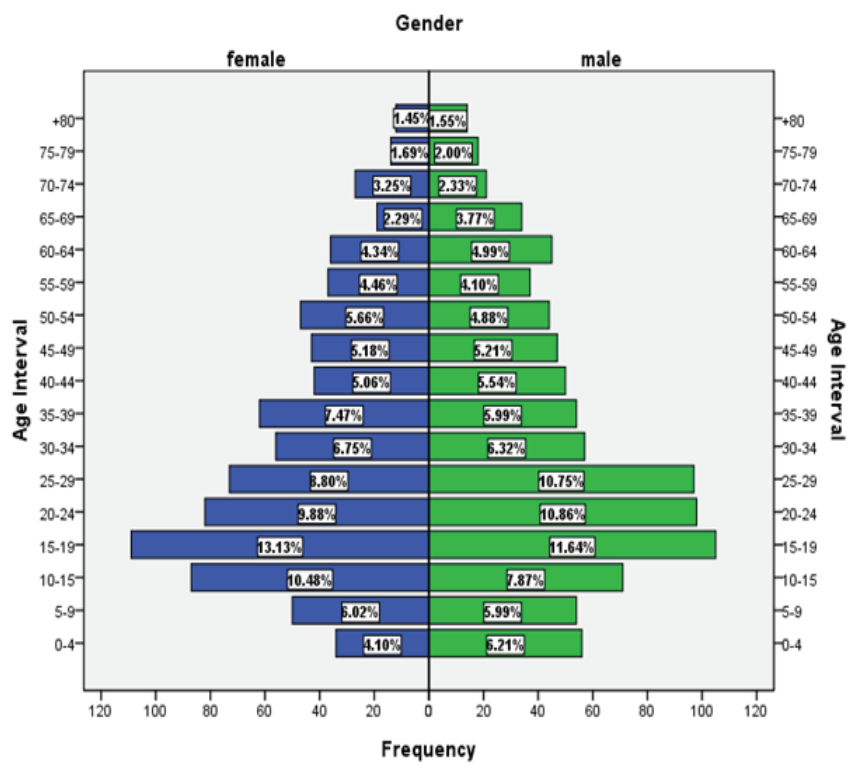

\section{Population distribution by ethnicity}

Out of 410 households, most of the people of Dhampus were Dalits (47\%) followed by Brahmins (34\%), Janjatis
(11\%), Chettris (8\%).

Fig 2: Population distribution of Dhampus VDC by ethnicity

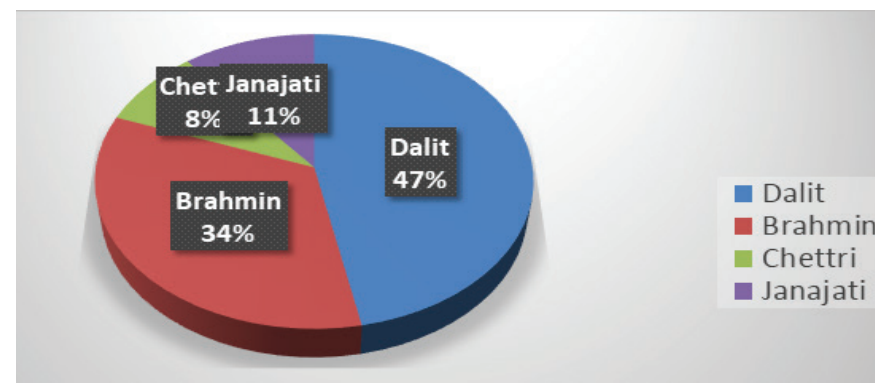

\section{Population distribution by religion}

Most of the people of Dhampus were found to be Hindus (91.9\%) followed by Buddhists (6.64\%), Christians (1.46\%), no religion $(0.24 \%)$ and none were found to be Muslims.

Table 3: Population distribution of Dhampus VDC by religion

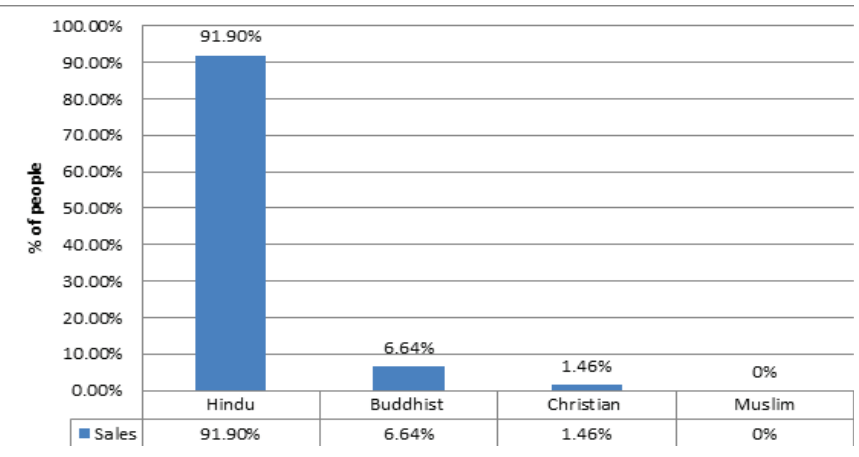

\section{Type of family}

Most of the families in Dhampus VDC were found to be nuclear (64\%) followed by joint (34\%) and extended (2\%).

Fig 3: Type of families in Dhampus VDC

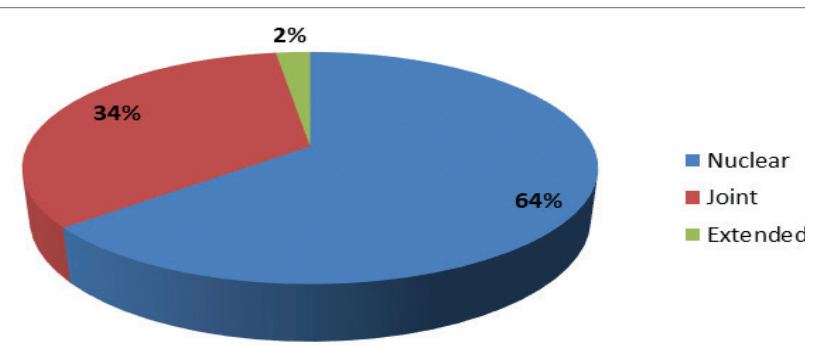

\section{Educational status}

Out of 1642 people with age above five years, most of the 
people of Dhampus were found to be literate (62\%). The educational status is given in the chart below.

Fig 4: Educational status of Dhampus VDC

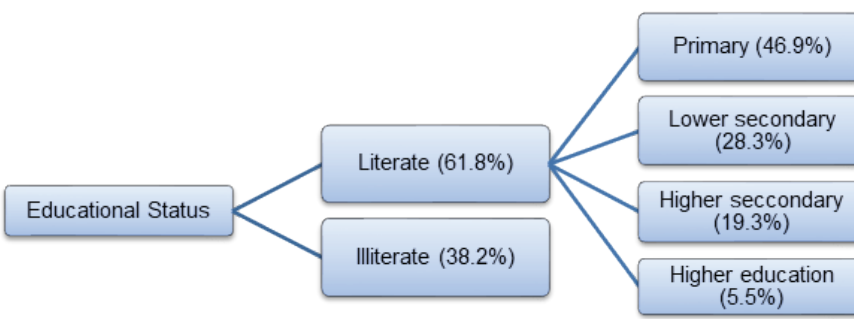

\section{Occupation}

Out of 1166 people of age above 20 years, most of the people of Dhampus were engaged in agriculture (71\%) followed by foreign employment (17\%), business (7\%), Government service (5\%).

Fig 5: Occupational status of people of Dhampus VDC

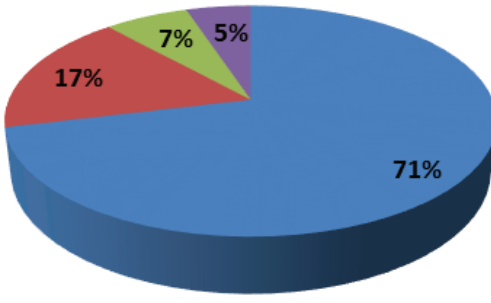

- Agriculture

- Foreign employment

- Business

Government service

Table 4: Occupational status of people of Dhampus VDC

\begin{tabular}{ll}
\hline Occupational status & Percentage \\
\hline Employed & $55.66 \%$ \\
Unemployed & $44.34 \%$ \\
\hline
\end{tabular}

\section{Smoking and drinking habit}

Out of total 1380 people of age above 15 years, 275 were found to be smoking and 141 were found to be drinking. The smoking and drinking habit of people of Dhampus VDC is shown in following bar diagram.

Fig 6: Smoking and drinking habit of people of Dhampus VDC

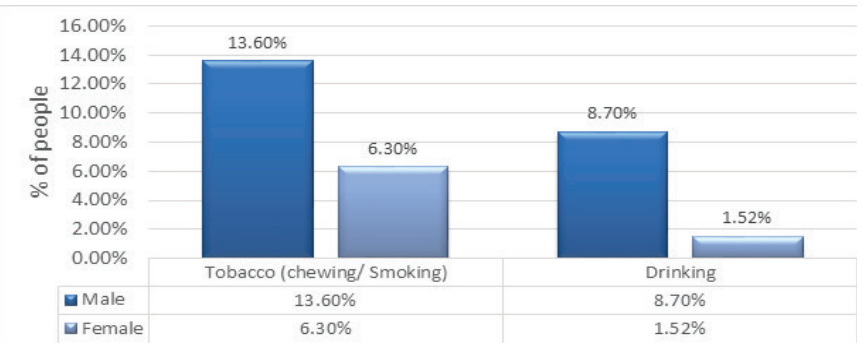

\section{Marital status}

The marital status of people of Dhampus VDC is given in the given pie chart.

Fig 7: Marital Status of people of Dhampus VDC

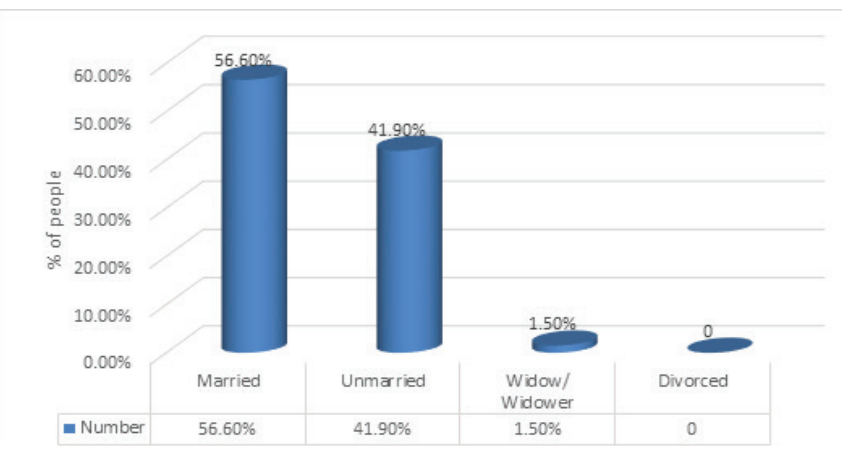

\section{MORBIDITY}

Morbidity refers to the diseases and illness, injury and disability occurrence in the population. By the knowledge of the disease one can know about the frequency and distribution of disease and also the causes and ways to control the spread of disease.

During our study in Dhampus, we came to know that, out of total population $6.29 \%$ people were diseased within 15 days. Among total diseased, 40.3\% were males and 59.7\% were females. The sex wise distribution of disease is given in following diagram.

Fig 8: Age wise distribution of disease among Dhampus population

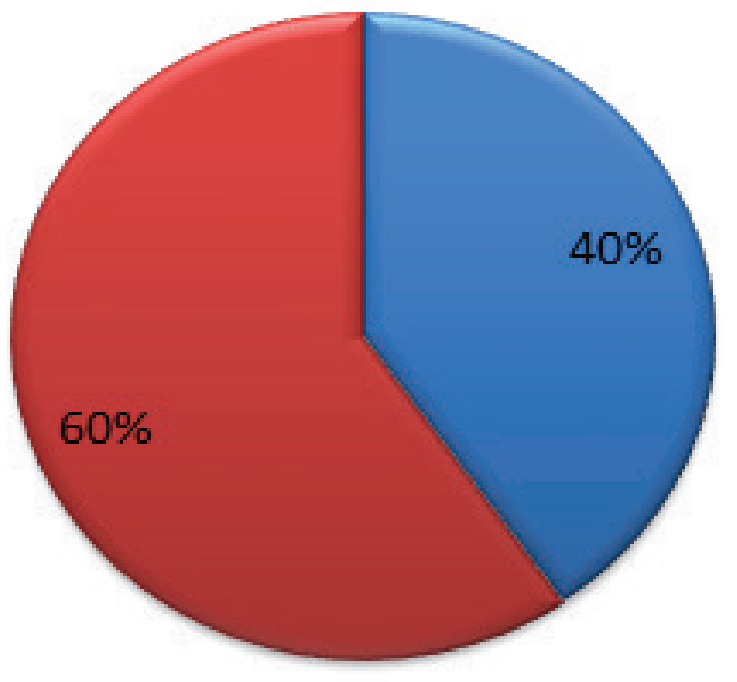

Male Female 
Most of the people visited health institution for the treatment. The way of treatment adopted by people during disease is given in following diagram.

Table 5: Ways of treatment adopted for disease among Dhampus population

\begin{tabular}{lc}
\hline \multicolumn{1}{c}{ Ways of treatment adopted } & No. of households \\
\hline Self-medication & $0.92 \%$ \\
Home remedy & $6.48 \%$ \\
Traditional healer & 0 \\
Health institution & $92.60 \%$ \\
\hline
\end{tabular}

\section{Disability}

Disability refers to the deviation from normal physical and mental functioning of the body. During our study in Dhampus we encountered four disability cases. Out of total study population, $0.23 \%$ were disabled. Among total cases of disability four were physical and none were mental.

Table 6: Functional distribution of disability

\begin{tabular}{cc}
\hline Physical & Mental \\
$100 \%$ & $0 \%$ \\
\hline
\end{tabular}

\section{Birth}

During our study in Dhampus, we found 39 live births within one year. Out of total live births within one year, 15 were females and 24 were males as shown in following table.

Table 7: Sex wise distribution of live birth within one year

\begin{tabular}{cc}
\hline Males & Females \\
$61.5 \%$ & $38.5 \%$ \\
\hline
\end{tabular}

\section{Mortality}

Death is a permanent disappearance of evidence of life at any time after birth has taken place. It is a vital event that affects structure, size and growth of population.

During our study in Dhampus VDC we found 10 cases $(0.57 \%)$ of death within one year among which six $(0.35 \%)$ were males and four $(0.22 \%)$ were females. Most of the people died because of old age as shown in following diagram.
Fig 9: Cause wise distribution of mortality

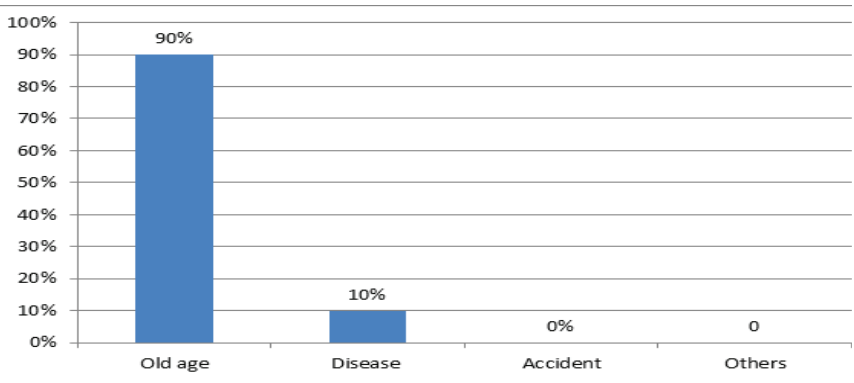

\section{Migration}

Migration is the geographical movement of individual from any usual place of residence for the purpose of establishing new permanent or semi-permanent residence. During our study in Dhampus we found three cases of migration among total population.

\section{Vital Event Registration}

It refers to the legal collection of data of vital events i.e. live birth, death, marriage and divorce of the specific population.

During our study in Dhampus, we found that most of the people have done vital events registration which is shown in following diagram.

Table 8: Vital events registration

\begin{tabular}{cc}
\hline Vital Events Registration & Number \\
\hline Yes & $82 \%$ \\
No & $18 \%$ \\
\hline
\end{tabular}

\section{Communication Media}

During our study in Dhampus, we found that most of the people uses mobile followed by TV, radio, telephone, computer and others which is shown in following pie chart.

Fig 10: Communication Media

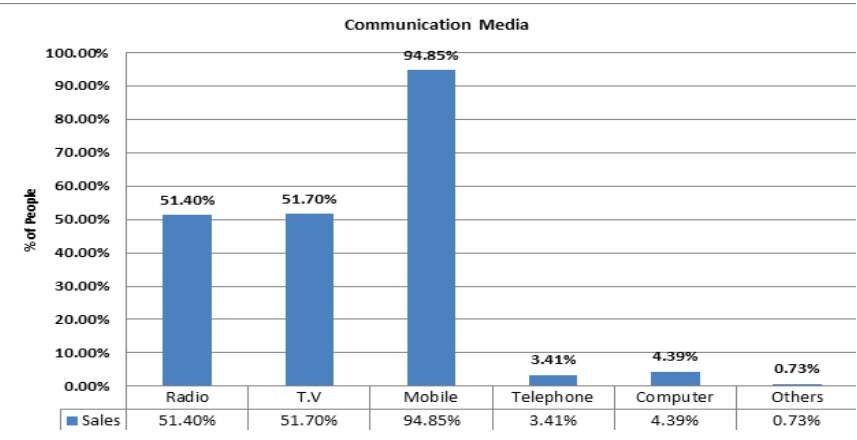




\section{CONCLUSIONS}

The herculean task we thought earlier was made possible by the regular support and fascilitaion of the helping hands which are even now sparking in our eyes. Those unforgetable experiences, skills and learning that we learned in such a short period of time make us indebted to them. Our accomplishment was not only regarding the community, but also huge experience of the team work, cooperation and mutual partnership in solving the problems. Our small efforts though can not bring the dastric change; the fire has been ignited towards the approach of healthy living and well being. Yes Dhampus had taught us millions of knowledge!!!

Community field daignosis worked as the platform to use our theoritical knowledge.To list out we learnt the following things from the field visit:

- To work in a group as a teamwork and with proper co-ordination.

- To build good rapport with the community people and remain with them as their helpers as one family.

- To listen to others problems and analyse their views on several health related issues.

- To convince people on our program and collect maximum information required

- Learnt about group dynamics and conflict management.
- Got acquainted with various religious and cultural aspects of community.

- Accomplishing community based learning

- Planning, implementation and evaluation of MHP

- To face any hardships or problems during the stay and try to solve accordingly.

\section{REFERENCES}

1. K. Park. Park's Text Book of Preventive and Social Medicine. 22 edition. Banrsidas publishers, Jabalpur (MP), India. 2013.

2. Sunder Lal, Adarsh, Pankaj. Text book of community medicine. Preventive and social medicine, CBS publishers. 2011

3. Lalita D, Hiremath, Dhananjaya A, Hiremath. Essentials of Community Medicine: A practical approach. Jaypee. 2010.

4. Subramaniam Mangala. Hand book of Community Medicine. Jaypee.2012.

5. AH Suryakantha. Community medicine with recent advances. Third edition. Jaypee. 2014.

6. Mahajan \& Gupta. Text book of preventive and social medicine. Revised by Rabindra Nath roy, Indranil Saha. Fourth edition. Jaypee.2013. 